\title{
Social Behavior in Public Spaces in a College Town
}

\section{Tim F. LiaO}

University of Illinois, Illinois, USA

e-mail: tfliao@illinois.edu

\section{Adam Rule}

University of Illinois, Illinois, USA

\section{Ryanne Ardisana}

University of Illinois, Illinois, USA

\section{Alexandra Knicher}

University of Illinois, Illinois, USA

\section{A manda Mayo}

University of Illinois, Illinois, USA

\section{Corey Sarcu ${ }^{1}$}

University of Illinois, Illinois, USA

\begin{abstract}
Public spaces provide an important venue for social and political behavior. In this research, we investigate social behavior in public spaces in an American College town. Three research sites in and around the campus of the University of Illinois at Urbana-Champaign are selected, and two kinds of public behavior - in the public and the private sphere - and private behavior are observed in the three locations. We seek to understand the relationship between public place and social behavior, types and variations of social behavior, and the importance of material or real public space. We find social behavior in the public sphere tends to concentrate in centrally located, symbolically powerful public places and that, despite increasing popularity of virtual public space, real or material public space continues to provide a vibrant environment for the public for their private as well as public behaviors.
\end{abstract}

Key words: Social Behavior, Public Space, Public Sphere, College Town, Photographic Observation.

1 Acknowledgements: Comments by Elizabeth Breese and Craig Calhoun on an earlier draft of the paper are much appreciated. 


\section{Introduction}

College towns in America offer a unique setting for studying social behavior in public spaces. With its auditoriums, stadiums, arenas, museums, concert halls, and landscaped grounds, the university campus is a hub of activities that serves not only students, faculty, and staff but also the larger population of a town and region (Gumprecht, 2007). Social behavior in a college town can certainly run the spectrum from individual to collective as the population in a college town consists of various interest groups among students, faculty, staff, and the general public. In this paper, we study social behavior in public places and its interplay with them in a Midwestern college town where the University of Illinois is located. Our research objective follows Gans's (2002) call for a renewed exploration of the connection between "space" and "society" since, as Gieryn (2000) put succinctly, all social life is "emplaced".

We consider three types of public space in this college town: publicly-owned, university-owned, and privately-owned public spaces. We expect to observe three types of behavior in public spaces-private behavior, private-sphere public behavior, and public-sphere public behavior. The concepts of private and public spheres follow those initially discussed by Arendt (1958) and Habermas (1989). We further define the types of public space and the categories of private/public behavior in later sections. In particular, we are interested in the following questions: What are the subtypes within each of the three types of social behavior? How is the type of social behavior in public space related to the type of public space? How important is public space in the age of virtual communications? The last question is about whether we are faced with the end of public space, or more specifically, the end of material public space (Mitchell, 2003).

We employed photography to assist our sociological study of social behavior in public spaces in this university town. Photography has long been established as a valuable means of sociological investigation (Becker, 1974, 1981, 1995). For sociological observations of behavior in public spaces, photography will be particularly useful because it can accurately record both the physical and the social environment of public spaces where individuals gather and engage in social action. Time-lapse photography or filming, for example, was applied in Whyte's (1980) classic study of public spaces in New York City. His goal, however, was to understand why some public spaces work (or attract people) and why some do not. Our objectives, in contrast, are to investigate the types of social behavior in public spaces and their association with the type of space. Photography, complimented by follow-up interviews, helped refine and further revise our typology of private/public behavior. To that end, we kept an open mind and held regular discussions of our field observations during the study. 


\section{Types of Social Behavior in Public Spaces}

A discussion of public space cannot be accomplished without a serious engagement with the concept of public sphere. Often public space is associated with a realm where public activities are performed. Arendt (1958) distinguished between the public realm (polis) and the private counterpart (household) by noting that decisions were made through speech and persuasion in the public realm. In contrast, the home was a place where men's and women's labor, not speech, were found and the business of the home was run.

Habermas (1989) laid down a systematic map of activities that explains the creation of the modern bourgeois state. According to Habermas (1989), activities in a modern bourgeois state are found in three spheres - the private sphere, the public sphere, and the sphere of public authority. The private sphere comprises conjugal family's internal space as well as the realm of commodity exchange and social labor that is part of civil society; the sphere of public authority is composed of the state, or realm of the police, and the court, or courtly-noble society; the public sphere mediates between the private sphere and the sphere of public authority, and consists of the political realm, and world of letters (clubs and the press), and the "town" or the market of cultural products. For Habermas, the relationship between private and public spheres needs some further elaboration because there are two public spheres: "the inauthentic public sphere of state authority, and the authentic one of private people coming together as a public through the public use of their reason. The authentic public sphere divides further into three aspects, which develop in the following order: first, the market of culture products; second, the Republic of Letters, with its institutions of intellectual sociability; and, third, the public sphere in the political realm" (Goodman, 1992:5).

It is important to note that, this sort of public-sphere behavior, be it political, cultural, or intellectual, often is displayed by private individuals. What is even more relevant for our concern in the project is that such public-sphere behavior can, and was once believed by scholars from Montesquieu to Tocqueville to Habermas to exist mainly in cafes and coffeehouses (Calhoun, 1993). The spaces in these places have always been private-in the past or present. It does not mean, however, that public-sphere behavior is confined to private spaces. There are indeed a variety of public spheres that may vary in the two dimensions of content and scale (Breese, 2011). Many types of public-sphere behavior can be found in public spaces. Even in the past, public-sphere events took place in public spaces. For example, many of the hundreds of public contentious gatherings and meetings in the eighteenth and nineteenth century Britain studied by Tilly (2010) were held in public spaces. Indeed, the distinction between public and private ${ }^{2}$ took on new importance in the postindustrial age when the realm of public interaction expanded, especially in cosmopolitan trading and capital cities where public spaces became more abundant

2 For a thorough treatment of the public and private distinction, see Weintraub and Kumar (1997). 
(Calhoun, 2010). In fact, smaller American college towns can also be prime locations for public-sphere action. Public events in Berkeley, California and Kent, Ohio in the 1960s and 1970s and Madison, Wisconsin last year are prime examples of public-sphere actions that shook (and in the case of Madison, was still shaking as of spring 2011) a nation but all took place in public spaces in small college towns. These public-sphere events all possess a common goal—collective identity—a "wefeeling" that is found still lacking in the current European Union where the sense of collective identity is low, pointing to the question of whether there can be a public sphere without collective identity (Eriksen, 2005).

Public-sphere events do not have to shake the world or a nation. "Street theater, street-corner speeches, marches, celebrations, vigils, leafleting, and other kinds of public acts seek to express collective sentiments or influence public opinion" (Oliver and Myers, 1999:38). These are clearly public-sphere behavior by Habermas's definition. Oliver and Myers (1999) studied such public events in Madison, Wisconsin where the police recorded 382 public events (45\% conveying a message, 14\% involving social conflict, and 13\% being standard protests) for one year in the city but the local newspapers covered just 32\% of all events, favoring large events and those involving conflict, sponsored by business groups, and occurring in central locations. Clearly, once a public event becomes represented in the mass media, the workings of the public sphere kick into a higher gear because a larger proportion of the public is at least informed, if not fully engaged.

Building upon the discussions this far, we define three types behavior found in public places. First of all, there is public behavior that belongs in the public sphere. The types of public acts listed by Oliver and Myers (1999), street theater, street-corner speeches, marches, celebrations, vigils, leafleting, and so on are often political in nature but they can also be purely cultural or intellectual. These acts involve more than a private group of people because a main purpose of all these acts is to reach out to a larger audience by expressing the ideas, be they cultural, intellectual, or political, of the participants and by exchanging their ideas with others, thereby forging some form of collective identity. We call this kind of behavior public-sphere public behavior because the act belongs in the public sphere and because it engages people that have not been part of the group before the acts begins. Is there such a thing as public-sphere private behavior that counterposes public-sphere public behavior? Of course not, because by definition behavior in the public sphere can only be public in nature. However, we need the somewhat redundant word "public" to help define the next concept, "private-sphere public behavior".

Many acts observable in public spaces can belong in the second type, private-sphere public behavior. Examples include vending on sidewalks, trading in pubic square markets, and promoting the interest of a private organization to the general public. These acts are public behavior because they engage people from outside of the group of initiators. They, however, belong in the private sphere where commodity exchange and other acts of civil society are performed, as outlined by Habermas (1989). A key distinction between private-sphere public behavior and public-sphere public behavior is that the latter facilitates the presentation and expression of ideas, 
be they cultural, intellectual, or political, as well as the exchange of such ideas with a larger audience. Such public-sphere public behavior possesses a collective goal that will presumably benefit a segment of the population larger than the group while the former type of behavior lacks such function. Here we adapt one of the distinctions between private and public discussed by Weintraub (1997), the distinction between individual and collective (by defining "individual" not as just one person but as any individual or private group).

Finally, very often acts found in public spaces are purely private. These are privatesphere private behavior or simply private behavior because they do not possess the purpose of reaching out to others outside the individual or private group. Examples include individuals walking in the street, couples conversing between themselves or kissing, and a group of individuals engaged in a private meeting. Much of what Whyte (1980) observed belongs to this type, people carrying on a conversation, lovers engaging in intimate dialogues, and individuals people-watching or simply relaxing and enjoying the sun. Institutional review boards today would frown upon observations of individuals' conversation, couples' behavior and other forms of personal behavior in public spaces without informed consent. This is because private information includes information about behavior that takes place in places including public spaces in a context in which an individual can reasonably expect no observation or recording is taking place (Bankert and Amdur 2006). As we see, a lot of acts and behavior found in public places fall into this category.

In summary, three types of behavior can be found in public spaces-private behavior, private-sphere public behavior, and public-sphere public behavior. ${ }^{3}$ In any given public space, private behavior must be the dominant type and we can expect to see it every day. We expect to see private-sphere public behavior less often in fewer public spaces, and public-sphere public behavior the least often and perhaps in more selective public places.

\section{Types of Public Space in a College Town}

In the public imagination, the term "public space" conjures up images of ancient Greek agoras, Mexican zócalos, and contemporary European city squares where communal life evolves in front of one's eyes. More relevant to our discussions, the term "public space" today reminds one of China's Tiananmen Square, Egypt's Tahrir Square, Libya's Green Square, and Tunisia's November 7/ Mohammad Bouazizi Square $^{4}$. As we discuss later, public spaces do not necessarily have to be owned by

3 Note that the nature of social behavior may change over time. Ordinary flows of human traffic may turn into a mob exhibiting collective behavior, as observed by Goffman (1963).

${ }^{4}$ November 7 Square, marking the date in 1987 when former President Zine al-Abidine Ben Ali took power, was renamed in February, 2011 after vegetable seller Mohammad Bouazizi whose self-immolation in December, 2010 sparked the protests that toppled the regime in Tunisia. 
the public. Our definition of public here follows Sennett's (2010) definition of public realm, where strangers would likely to meet; in contrast, in Sennett's private realm, which is a private place where complete knowledge of its members is present. Moreover, the gathering of strangers in public places enables certain kinds of activities and behaviors that are not possible in private places (Sennett, 2010).

University campuses, especially those public universities located in small or medium-sized towns in the US with landscaped grounds that are open to all, constitute a uniquely American experience of public space. While institutions in major metropolitan areas often face serious security concerns and high demand for their facilities, universities in smaller towns in the US, with their concert halls, museums, stadiums, and well-kept grounds, serve as both a site for learning and a public space that is central to college town life (Gumprecht, 2007).

University campus as a public space consists of multiple public places. ${ }^{5}$ However, how places are structured can facilitate or impede collective action. For example, the famous Haussmann Renovation of Paris in the late nineteenth century fractured some of the working class residential clusters in neighborhoods replete with cabarets and cafes where workers mobilized in 1848 (Gieryn, 2000). We can make similar observations about college campuses. As Tickamyer (2000) pointed out, the design of the campus and its surrounding areas could facilitate or impede demonstrations, protests, and other forms of social mobilizations. Therefore, all public spaces are not equal, and we should expect public-sphere behavior to occur more often in certain types of public space than others.

In this project we focus on different types of public space only. Sometimes, however, the boundary between public and private space (and time) can be blurred. Examples include taking a nap at the workplace, when the place for a private activity like sleeping is shifted (Baxter and Kroll-Smith, 2005). In addition, we focus on outdoor public spaces primarily, or at least public spaces outside those indoor areas that are confined to a unique functional purpose. As Gumbrecht (2007) identified, concert halls and museums are examples of public space. By the same token, libraries, especially those at state universities, are supposed to be open to the general public, and certainly constitute public space. However, the kinds of social behavior in these types of public space are typically limited by the functional purposes of these facilities: People go to libraries to read, study, and borrow books; people visit museums to see exhibitions; people gather in concert halls and performing arts centers to attend lectures, symphonies, or other performances.

In this research, we define three types of public space: publicly-owned, universityowned, and privately-owned public space. Examples of publicly-owned public space

5 Put simply, "place is space filled up by people, practices, objects, and representations" (Gieryn, 2000:465). In this project, however, we use the two terms "place" and "space" interchangeably because we already distinguish social behavior (i.e. public sphere versus private sphere) from its environment (i.e. public space). 
include all the afore-mentioned public squares, public streets and sidewalks, and public parks. (Technically, sidewalks next to private properties are owned by property owners but offer public right of way. Here we consider them, together with other really public owned places, as publicly owned because their access is never controlled). These open areas are accessible by all citizens regardless of the purpose of their visits.

Bearing a close resemblance to publicly-owned public space is university-owned public space, at least for spaces owned by public universities. On a university campus there are many open-access areas that are owned by the university. In addition to the list already presented (i.e., concert halls, museums, stadiums, lecture halls, and so on), there also are open, often landscaped spaces including courtyards, quadrangles, squares, and terraces that are conducive to public gatherings. Although university owned, their access and use are open to all (a description true at least for state universities). Because the university owns campus public spaces, it can regulate its use as well, especially when it comes to public-sphere public behavior. In 1964, the University of California at Berkeley regulated such use by moving the free speech, "Hyde Park" area from a stretch of sidewalk to the plaza below the Student Union (Mitchell, 2003).

Finally, privately-owned public space has increasingly become available in contemporary America. In the second half of the twentieth century, the spread of the suburbs and their shopping malls have greatly affected the shape of public spaces in the US for they have become a major attraction in their own right instead of merely a gap between stores (Carr et al, 1992). The same can be said about urban malls, which experienced a wave of regeneration in North American center cities in about the same period. Some of these urban malls, such as Atlanta's Omni International (now Peachtree Center), Detroit's Renaissance Center, and Toronto's Eaton Place, are indoor megastructures with a controlled environment of a large scale (Carr et al, 1992). The list of such malls in recent years is extended to other parts of the world including places that are not traditionally European or North American, such as the Bilkent Shopping Center in Ankara, Turkey (Erkip, 2003). These urban and suburban malls gradually take over some of the functions played by public squares and plazas of yesteryear. Although they are privately owned and do not open their doors at night, they are still popular as public spaces for people to gather and hang out.

Are there certain types of public space that attract certain types of social behavior more so than others? The issue is quite similar to what Gans (2002) focused on: the causal relation between natural space and social space, because, strictly speaking, public sphere is a social space. In Gans's (2002) use-centered approach to space, he identified land use, land values, location, density, propinquity, public space, neighborhood, community, and political economy as key concepts. For our study of how

$\mathbf{6}$ The term "Hyde Park" is often used as a synonym for a public space for free speech in the public sphere. Its historical origin is Hyde Park, London where working people held an assembly in support of the right to vote in 1866 (Mitchell, 2003). 
social behavior relates to public space in a college town, specifically, the issues of location, density, and propinquity are particularly relevant.

\section{Research Design}

The research locale is Urbana-Champaign, Illinois where the University of Illinois is located. The university in Urbana-Champaign is the flagship campus of the University of Illinois system. A land-grant institution, it was established in 1867, and has currently over 40,000 enrolled students and over 3,000 full-time faculty. The campus straddles the twin cities of Urbana and Champaign, each of which has its own downtown areas. Together with Campustown, there are three downtowns in this college town.

To best study social behavior in public space, we identify three research sites, Campustown, the Main Quadrangle, and downtown Urbana (Figure 1). Campustown is located in the east end of the city of Champaign at the edge of the campus. Its core covers an area two blocks wide and three blocks long, defined by the west side of Wright Street on the east, the east side of Fourth Street on the west, the north side of Green Street on the north, and the north side of Daniel Street on the south. Side streets extending from this area as well as a few blocks of Green Street westward beyond Fourth Street can also be considered part of the larger Campustown. Certain public spaces are recognized as a refuge for homeless people (Mitchell, 2003). Locally, Campustown is an area that the homeless frequent. The Campustown area contains streets and sidewalks that are publicly owned, or more specifically, owned by the local government, and has several scores of eateries and other businesses.

Figure 1

The locations of the three research sites in Urbana-Champaign

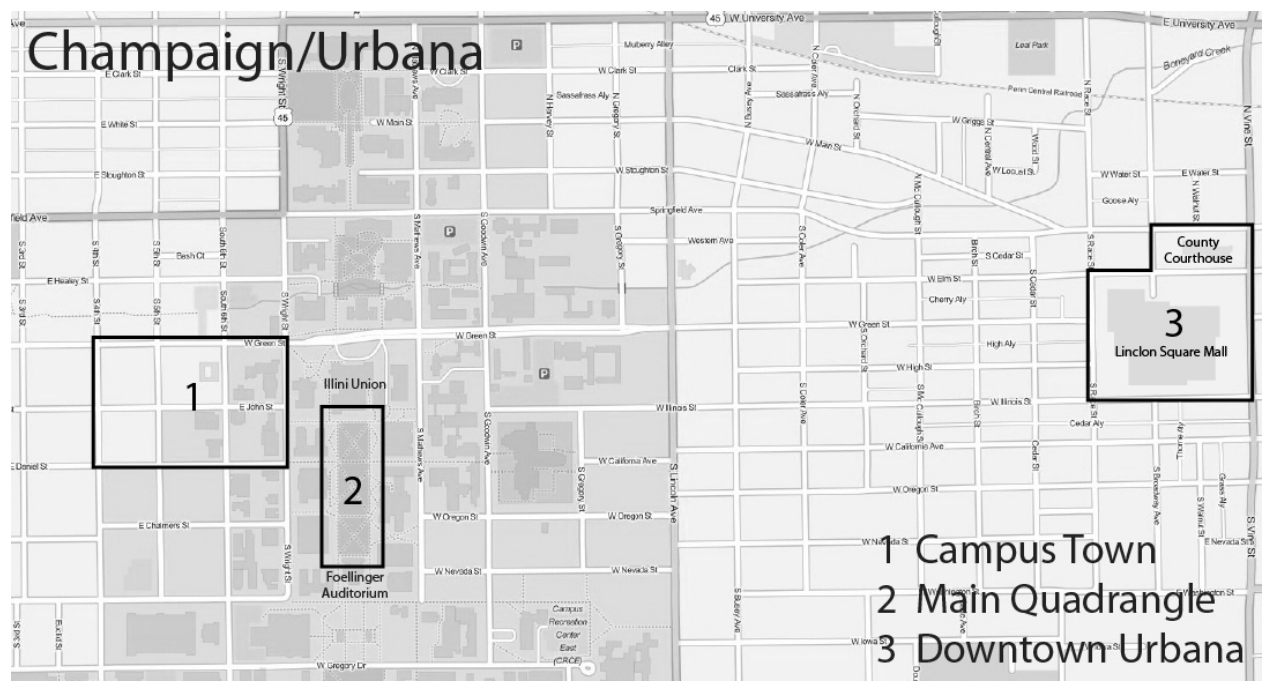


The Main Quadrangle, including the sides of Illini Union on the north end of the quadrangle and the sides of Foellinger Auditorium on its south end, is our second research site. This area is university owned. However, it is used and accessible by all citizens. The terrace outside of and the entrance steps leading up to Foellinger Auditorium and the south side terrace area of Illini Union are popular places for public gatherings. Sometimes marches and protests originate from and end at the south side of Illini Union.

Our third site, downtown Urbana, has a mixture of public spaces. There are two cores in this downtown area. One is the open area/plaza outside the county courthouse. Sometimes the public gather there to express their opinions and protest. The other is Lincoln Square Mall, which is an indoor shopping mall though in recent decades it has had trouble securing an anchor department store in the past two decades. Currently it has some small arts and crafts and souvenir stores, restaurants, a healthy food grocery, a gym, and office space. What is so unique about this mall is that the indoor area is rather wide and airy, usable by community groups for events as well as art shows and performances. The parking lot outside the mall on the east holds a Saturday farmers market, known as Market on the Square, which runs from the beginning of May to early November each year. ${ }^{7}$ Thus, we have a mixed publiclyowned public space and privately-owned public space in downtown Urbana.

We confined our field observations in these three sites. This strategy differs from the extended place method employed by Duneier (2001) who made field research of sidewalk vendors on Sixth Avenue, New York by extending his observations to the public toilets the vendors used and local restaurants linked to the sidewalk scene; the interviewing off the block grew out of participant observation on the block. In contrast, we employed a specified space method because our interest focuses on social behavior taking place in physically defined public spaces. What happens outside the spaces, albeit relevant for understanding the origin and perhaps the consequences of social behavior, is beyond our research objectives in studying public spaces.

For making observations in the planned research, we used photography as a research method. Photography is particularly suitable for research on public space because public spaces and their contexts and occupants can be captured by cameras and presented on photographs for later analysis. Moreover, visual methods have been employed by sociologists for decades (Becker, 1974, 1981, 1995). We conducted the research in both the scientific mode and the reflexive mode discussed by Harper (1988). We take photographs to record the world, especially the social world. In that sense, photographs are our data for scientific analysis. However, it is also important to ask our subjects to reflect on the meanings of these photographs. We think a photograph we have captured contains, say, public-sphere public behavior, but does the subject photographed think so as well? By interviewing the subject (after obtaining informed consent), we will be able to gain a deeper understanding

7 There is also an indoor holiday market in Lincoln Square Mall from mid-November to a week before Christmas. 
of what may be going on beyond just the surface. Riley and Manias (2003) suggested that we view a photograph in three possible ways by looking at it, looking through it, and looking behind it. Without information from our subjects, we most likely can only look at a photograph and tell a story from only the image superficially. With information from them, we will likely be able to look through an image to see meanings internal to it, and look behind it to examine its context.

Multiple researchers conducted field observations in each of the three research sites during the 2011 January-May Spring Semester. These observations covered both weekdays and weekends at randomly chosen times of the day. We made certain that special public events taking place in these public spaces are observed.

\section{Analysis of Social Behavior in the Research Sites}

In this section we analyze our observations in the three research sites. As shown below, the sites share some similarities in social behavior but also exhibit some differences. Two of the sites are adjacent, and activities fro one place can spill over the other even though they may not penetrate deep into the heart of the other area.

\subsection{Campustown}

The Campustown area begins at the northwest corner outside the Main Quadrangle. Protests, marches, and speeches are all commonplace on campus and can spill over to Campustown.

Figure 2

Public social protest

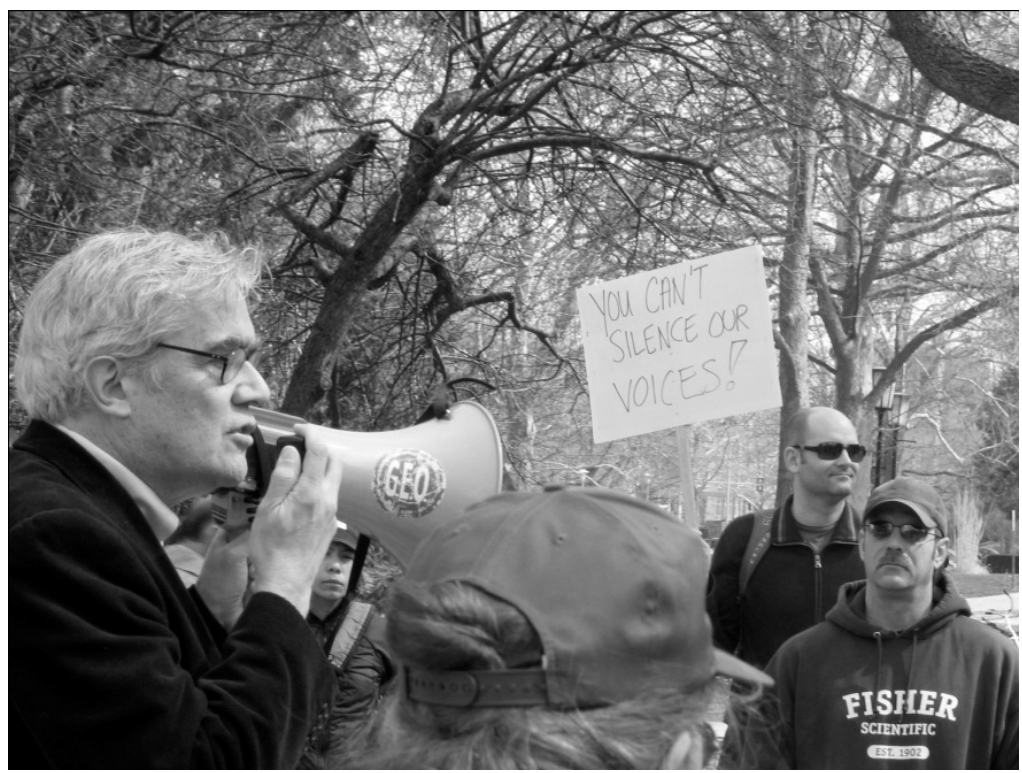


Public-Sphere Public Behavior. Figure 2 shows a protest that took place just off Green Street. Members of the protest included students and faculty of the University. A Graduate Employee Organization (GEO) sticker can be seen on the side of the megaphone as the speaker talks to the group assembled around him. The group was protesting the University's plan to increase tuition rates for the next year. A fellow protester in the background holds a sign reading, "You can't silence our voices!" The group was assembled next to the Alma Mater, the most distinguishable statue on campus whose outward stretched arms welcome students, alumni, and guests to the campus. It is located just outside the Main Quadrangle with Campustown proper across the street. It is hard to believe that the location choice was unintentional, placing a protest against measures that could bar entry for students of low socioeconomic status to the University next to the University's most welcoming symbol.

While the social presence of the protestors is unmistakable, there are other, less obtrusive ways that public discourse is carried out on campus. Various media including leaflets, flyers, chalk drawings and signs adorn Campustown. Added to the normal texture of advertising in public space is a plethora of information in the public sphere. For example, fliers educating passers-by about the current state of affairs in the world were observed on a light pole: one detailing protests in Wisconsin against cuts in public employee benefits and collective bargaining rights, while the other details turmoil in the Arab world in what is now being called the Arab Spring. Tape and residue above the signs show that they are by no means to be the first to have adorned the post. While people walking by are less likely to take notice of information presented in this manner, mediated public behavior also allows for an efficiency of discussion. Not needing to stop and wait through minutes or hours of speeches, students, faculty, and community members on their way to other engagements can take pull-tabs from many of the posted signs or write down websites chalked on the sidewalk for consideration at a later time.

Figure 3

Public communion

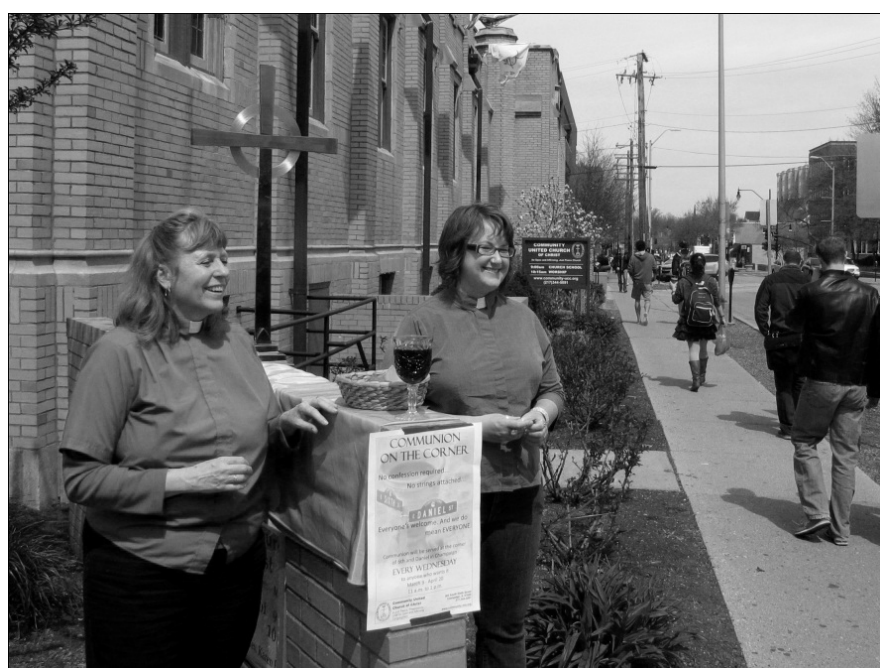


Private-Sphere Public Behavior. Private-sphere public behavior also abounds in public spaces. Sidewalk vendors sell their goods up and down Green Street and established shops line all of Campustown. Private groups, fraternities and social organizations can often be seen promoting their groups and asking passers-by to sign up for mailing lists. One of our observations provides a unique view into private-sphere public behavior on campus (Figure 3). Two pastors, Subjects A and B, are waiting outside their church during the season of Lent to administer communion on the street. An interview with them revealed inclusivity as their motivation. They spoke of students who had not had communion for years because of the high bar for administration that many churches place on the sacrament. They stated that by not requiring confession and by allowing persons with homosexual orientation to take communion, they were providing a "life preserver" to many students. The sacrament is treated with some respect, a purple cloth lining the sign they placed the elements on and aesthetic principles of order and symmetry still adhered to strictly. Not many services on campus however are so freely given.

Figure 4

Homeless Richie

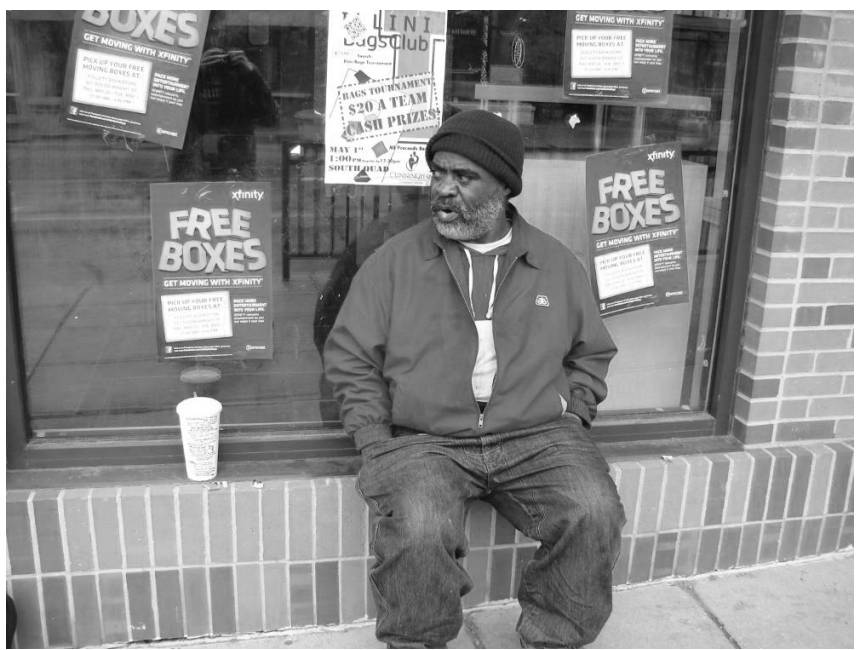

It is common to see panhandlers out in public in American cities including this college town. The homeless tend to have a favorite place as refuge in a city, like People's Park in Berkeley, California (Mitchell, 2003). Campustown is one such place. In Figure 4, a homeless man, Subject C or "Richie," sits outside of a commercial eatery on Green Street close to a bookstore. Dignified and unharassed, Richie is being ignored by most of the people walking nearby. With no private space to call his own, Richie sometimes sets up camp for a few hours along Green Street to beg passersby for subsistence money. As a legal American citizen born and raised in Champaign, he has every right to wait on the sidewalk and ask for alms, whereas if he were to try the same within an eatery, he might be asked to leave. At the time of this observation, he and his two younger brothers had not eaten for two full days. Richie's 
eagerness to tell the observer his life story displayed a level of trust and private sharing unexpected from a homeless man. The area he chose to sit in represents a private zone. However, because Richie actively reaches out to others with his own private needs, his actions represent private-sphere public behavior. His livelihood to a degree depends on his interaction with passers-by. Regardless of whether individual attitudes towards the poor are compassionate or not, those in need are freer to wander the roads and ask for spare change. The photo shows him not to be timid and weak like the impoverished of old, but well-established in his space, willing to reach out to individuals for help.

Private Behavior: Finally, private-sphere private behavior abounds in Campustown. Examples include friends going out to eat or study together, students walking to class, listening to music, checking their phone for messages, or reading notes on the way to class. On one such an occasion, a group of students are studying outside of Starbucks on Green Street in the early evening hours. The time is social, shared over drinks with phones out on the table in case other friends call. Each student in the group was studying a different subject and would often take breaks to check their phone, or talk to their friends around the table. The atmosphere is inviting but private, with students showing some sign of anxiety if passers-by got to close.

Another common scene in Campustown has students and faculty crossing some of the busy intersections, such that of Green and Wright Streets during a passing period. Most persons act individually, ignoring other people in the street, listening to music, or talking on the phone. Cell phones have revolutionized the use of public space for private behavior, allowing for the use of any public space to become private. While they allow for some sense of social presence with friends, family, and coworkers it also seems that social connection with those in their immediate surrounds is being lessened.

\subsection{The Main Quadrangle}

Public-Sphere Public Behavior. Students often use the main quadrangle (the Quad) as a social space to spread their ideas to the larger public while attempting to help others. This behavior certainly qualifies as public-sphere public as defined earlier, as it involves individuals or groups staging social protests (as in the example just outside the quadrangle shown in Figure 2) or taking time to help members of society who are not themselves part of the group.

Public-sphere public behavior can involve raising money for an organization to benefit the larger society or simply raising awareness for a cause. For example, the sorority Delta Kappa Delta placed a sea of pinwheels on the quad during CHILD (Changing Hope Into a Lasting Difference) Week to raise awareness for child abuse. They included a sign, reading "April is Child Abuse Awareness Month: These pinwheels are in honor of each child who suffers." Subject D, a member of the Delta Kappa Delta sorority, shared that her organization also sold shirts during CHILD Week to raise money to help put a stop to child abuse. By placing the pinwheels 
and sign in a central campus location such as the Quad, their display caught the attention of thousands of student, community members, and faculty and staff, and undoubtedly did a small part to promote a cause they felt was worthy.

Figure 5

A student environmental group organized bicycle tune-up service on the Quad

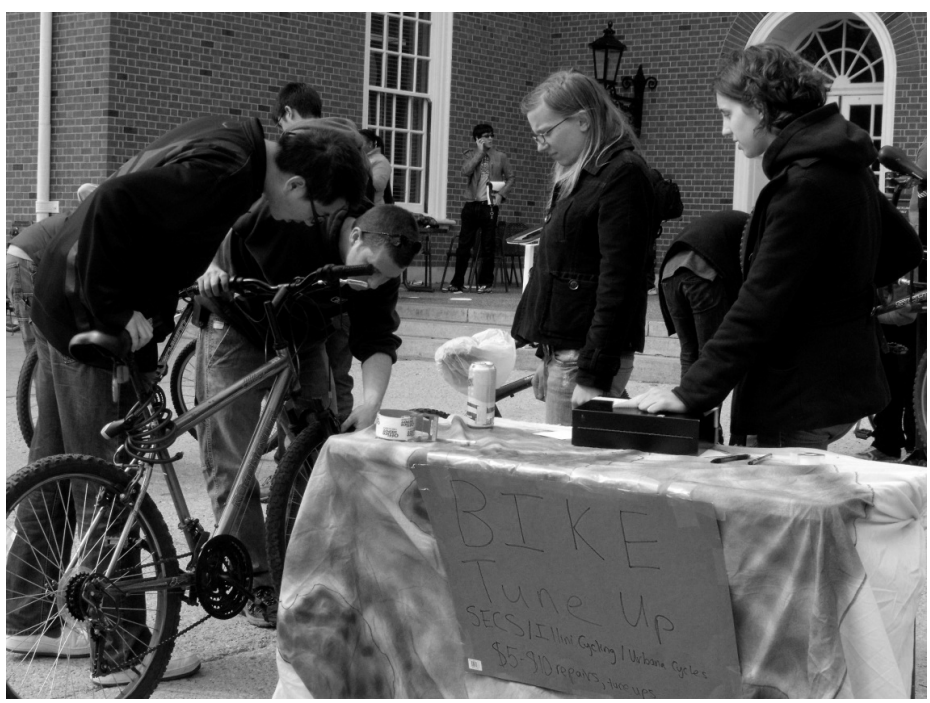

Shown in Figure 5 is a student environmental group raising money from providing bike repairs and tune-ups. Booths like this that has an environmental concern or raises money by means such as a bake sale for a charity are common sights on the Quad. They not only exemplify how students get involved outside of their class work, but in addition they display the efforts of bringing awareness to college students as well as including "outsiders" in their organizational activities. It demonstrates that the public sphere can involve as broad participation as possible. It also supports Breese's (2011) scheme of public spheres with one end being face-to-face interaction. The Quad as a public space for events like this is used by students to directly connect with other students and nonstudents in order to get them involved with their organization and to communicate current issues and fundraising needs.

Private-Sphere Public Behavior. Though many public-sphere public behaviors as well as variations of public behavior that overlap the public and private spheres can be observed on the Quad, there also exist many instances of purely privatesphere public behavior that engage outsiders but are intended to benefit group members only rather the larger society. With over 800 Registered Student Organizations (RSOs), not to mention Greek organizations and outside visitors, the University of Illinois campus is constantly home to groups who congregate on the bustling quad in search of support. 
No matter the season, day, or weather, the Quad serves as a constant reminder of events taking place around campus. Group members are often present at a booth to promote their organizations (especially on the once-a-year Quad Day prior to the fall semester). But when members of a group cannot always be present, or when they want to advertise an event for an extended period of time, they often "chalk" the sidewalks of the quad to catch the attention of passers-by (Figure 6); sometimes more fliers are found in the north end of the Quad, such as on a large concrete column behind the Illini Union, than in the Campustown area. By doing things like these, students can ensure that their organizations will be known to all people passing through the Quad for several days, without much further effort for face-to-face interaction. Often, when events are drawing nearer, or when an organization is attempting to raise funds, group members will set up on the Quad to actively engage passers-by. Group members will go to extreme measures to get the attention of students by dressing up, using megaphones, selling treats, and chasing down walkers to ensure they are given fliers.

Figure 6

One of the many chalk drawings promoting a fashion show by the Vietnamese Student Association

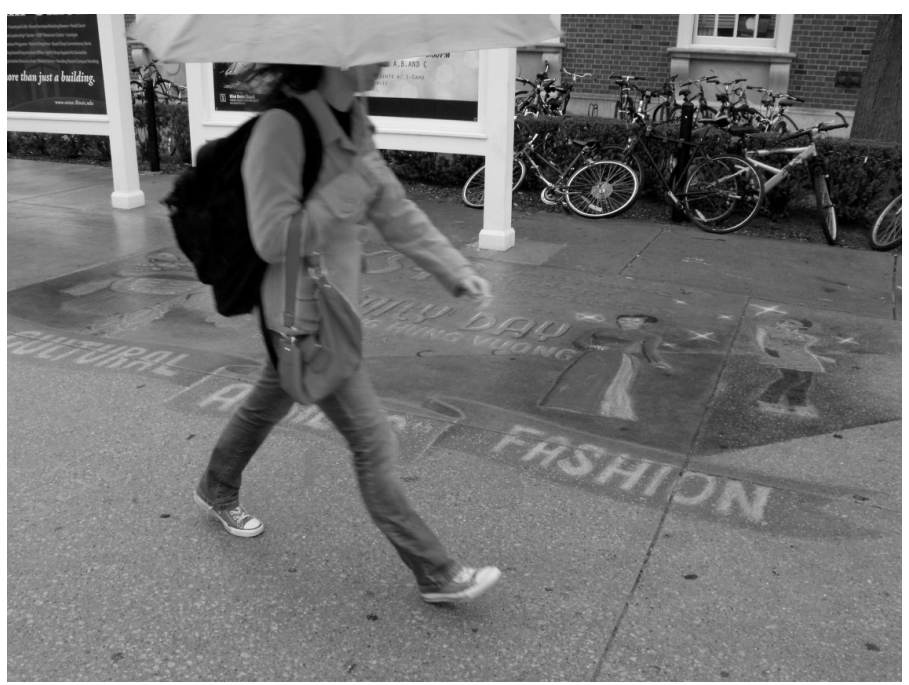

Especially extravagant chalk drawings are an extra cause for attention because of the great talent it takes to create them. The advertisement shown in Figure 6 advertises an upcoming fashion show. This masterpiece may be washed away by rain and new "chalk flyers" constantly embellish the sidewalks of the Quad. Not only that, but students will hand out and also post pages upon pages of flyers to promote their event, fundraiser, or campaign. Most campuses have this type of pillar for this very reason, and university students know that the latest organizational news can always be found there. Because of the vast amount of young minds, future politicians, 
potential activists, and student thinkers on campus, students and organizations know it's important to "get the word out." Especially for events or fundraisers, the best way to communicate to busy students is to first get their attention, and the Quad enables them to do that. This public place allows all groups to contribute their say, their point of view, their campaign, and their organization, to the collective student body. In that way, this use of the Quad relates to Breese's description of "mediated public spheres...facilitated by mass media" (Breese, 2011). Just as companies use advertisements on television, in magazines, and on billboard to communicate with citizens of a city or a village or even an entire country, so do university students advertise to their fellow peers in the student body.

Private Behavior. The most obvious and striking quality of the Quad is the sheer amount of people that walk on its paths every day. Many of the buildings which hold classes on campus are located directly on the Quad or are in nearby surrounding areas. Bus stops are also located on the outer edges of the Quad. The Student Union located on the north end of the Quad holds a café, rooms for studying, recreational activities, and more. For these reasons and more, the Quad is one of the high traffic areas on the entire campus.

The sidewalks and paths on or near the Quad are often packed on school days, even on rainy days, more so than a city street is. Students stream out of the buildings and go wherever they need to go by walking, biking, boarding, or rollerblading. Even while classes are going on, there is still a constant flow of people passing through the Quad. Several interviewed students commented that it is simply one of their main paths to get to where they need to go, especially classes, while others go in their free time to see if there is anything interesting going on. In terms of public space, this use reflects the nature of a public space as being used simply out of necessity. People need to be somewhere, and based on location and provided pathways, they use the Quad as their means of travel.

While the Quad is certainly a place where groups can attract the attention of others, more often than not it is simply an area for private activities for individuals wishing to keep to themselves though on view for the public. This type of behavior can include individuals or groups of people doing activities for pleasure, school, and anything in between. Individuals use the Quad daily for a plethora of activities. They can be seen talking on the phone or studying. Its relaxed ambience and central location make the Quad an ideal location for students wishing to have some low-key study time or just a break between classes. This grassy expanse usually accommodates individuals who are not trying to engage others, as opposed to the bustling north strip behind the Illini Union described earlier. 
Figure 7

One of the many chalk drawings promoting a fashion show by the Vietnamese Student Association

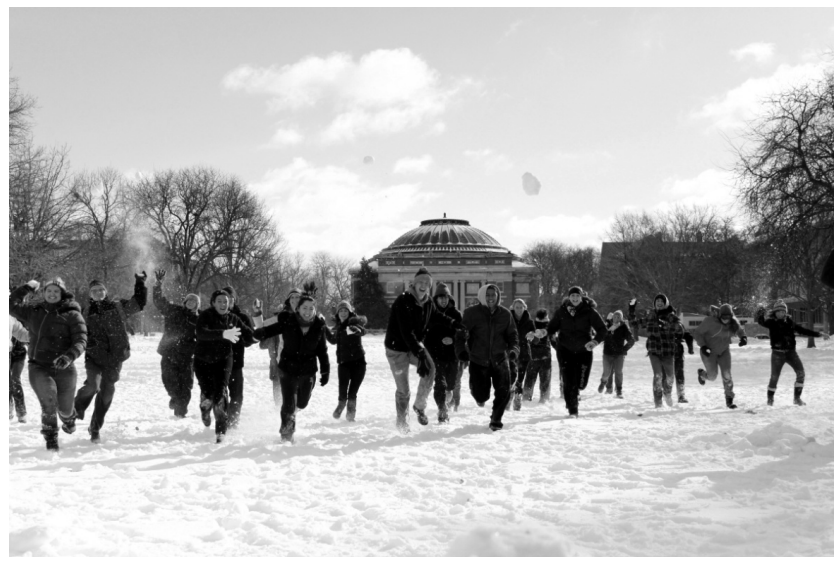

As well as individuals and couples enjoying the Quad privately, groups of people often gather to this large open area. In the warm days of fall and spring, the Quad is practically never seen without a group of students playing Frisbee or a group of friends sprawled out on the grass talking together. Generally in the colder months, the Quad does not see as much action, but even then it is put to use. Figure 7 shows a group of students who met on the Quad to have a snowball fight on one of the University of Illinois' rare snow days when classes are suspended. As snow days do not come often to the university, most students were in extremely high spirits, and wanted to get out and take advantage of this rare opportunity. Subject E, a participant in this snowball fight, shared that the group of friends coordinated the event via Facebook, and then decided on the quad as a meeting place because they knew it would be a close walk for everyone and provide the largest area. Though this large group of students was certainly rowdy as they played, they had no desire to promote themselves as a group or make a political statement; they were merely a group of friends using the Quad as a public place to have a good time. The array of similar leisure activities on the Quad is nearly limitless. On any given day, one may find tightrope walkers set up between trees, cheerleaders practicing stunts, community members walking with their family or dogs, or even jugglers and unicycle riders.

For example, Subject F, a student (not pictured) who was playing Frisbee at the time during one observational period, commented that playing sports is one of his favorite things to do in his free time, and the Quad is one of the places on campus that provide a nice open field to get a good game in. Not only that, but he claimed that playing there caused strangers to join, which usually made the game more enjoyable. Besides sports, people are often seen reading books, taking a nap, and talking on the Quad. When discussing the University of Oklahoma, Gumbrecht (2007: 85-86) described the campus as being popular in all seasons: "Students throw Frisbees on the North Oval, while others sunbathe nearby....(and) when it snows, 
for example, a hill in Brandt Park provides the best sledding in town." Similarly, the Quad at all times of the year brings students and community together in a way that most areas in town cannot hope to achieve. The clean-cut landscaped grounds and inviting Illini Student Union creates a welcoming environment that brings together academic minds, sports fanatics, and retired alumnus. Here, this university public space acts as a park, a meeting ground, and a place to take some time off from school or work.

\subsection{Downtown Urbana}

Public-Sphere Public Behavior. Public space is intended for public use and after observations in downtown Urbana it is clear that public space is well utilized by the public. Downtown Urbana showed all three types of social behaviors we expected. It was anticipated public-sphere public behaviors would be found the least frequent of any behaviors. Over the course of the study, we only observed one public-sphere public behavior in downtown Urbana on the days when observations were made.

Unlike Campustown or the Quad that are more centrally located and may attract people who intend to engage in public-sphere action, downtown Urbana is much less so. This may have to do with its less central location (as compared to the University campus) and possibly its lack a similar kind of symbolic power that the University possesses unless some public action is directed to the City of Urbana or the county government.

Figure 8

Booth for signing up for Urbana Library cards at Market on the Square

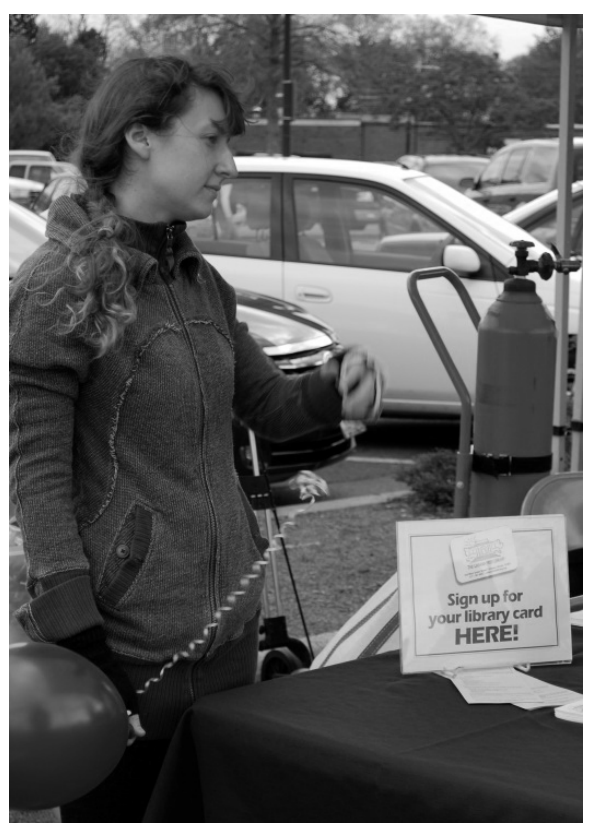


Urbana's Market on the Square is the only place where we observed the publicsphere public behavior in downtown Urbana in the course of the study. Figure 8 shows Subject G handing out balloons to children and families who were signing up for library cards at the Urbana Public Library. This is a public-sphere public behavior because her organization, the Urbana Public Library, was reaching out to others by inviting them to sign up for free library cards and encouraging them to read, thus benefitting the larger public in the city.

Private-Sphere Public Behavior. As anticipated, private-sphere public behaviors were found less often then private behaviors but more often then public-sphere public behaviors. Lincoln Square Mall has a number of businesses. One of them, Hallmark, had moved their Easter products along with other various clearance objects into the public hall of the mall to draw the attention of the public walking by. This is a perfect example of what we defined as a private-sphere public behavior. Hallmark is a private firm promoting their interests to the general public. Although they are involving people outside the organization, the behavior is still considered privatesphere where commodity exchange and other civil acts are performed, as outlined by Habermas (1989). One woman, Subject H, browsed through the clearance items displayed right outside the store. Subject $\mathrm{H}$ admitted she was not looking for any thing in particular, "the table just caught my attention." She did not even walk into the actual Hallmark store, simply browsed the table displayed in the public hall. This was not uncommon either. In about a half hour, 15 people were observed browsing the clearance tables outside of the store but never actually enter the store itself. The observation made outside of Hallmark suggests that such behavior is a great tactic to promoting business and organization's interests to the general public.

Market on the Square is a farmers' market located in the east parking lot of Lincoln Square Mall that runs from the beginning of May until early November. Our study ran just long enough to observe the first Market on the Square on May $7^{\text {th }}, 2011$. Market on the Square was full of good examples of private-sphere public behavior. Private organizations and individuals were promoting their interests to the general public in the form of commodity exchange type of private-sphere action as (Habermas, 1989). There were all kinds of venders at the market including fresh produce, cut flowers, jewelry and potted plants. We observed Subject $\mathrm{H}$ going about her duties at the Tiny Greens stand, such as waiting for costumers, cutting the wheatgrass, and juicing the grass while the costumer waits. As she cut and juiced, Subject I, who is a graduate student in landscape architecture at the University of Illinois, said that Tiny Greens has a stand at almost every farmers' market and they get a lot of business from locals and university students at the market. The observation at Market of the Square suggests that private-sphere public behaviors in one central place, like this parking lot, can be a great crowd drawer for locals and university students.

Private Behavior. As anticipated, private behavior was observed with the highest frequency in downtown Urbana. In fact, it was observed multiple times on a daily biases in all areas of downtown Urbana. Private behaviors were defined as behaviors not intended to reach out to people outside the individual, couple or private group but still involve the use of public space. Observed private behaviors had a 
wide range from individuals, couples and groups of people walking, talking and playing on Urbana's public space. The examples below represent some of the most common types observed.

Figure 9

Two old friends catching up and chitchatting

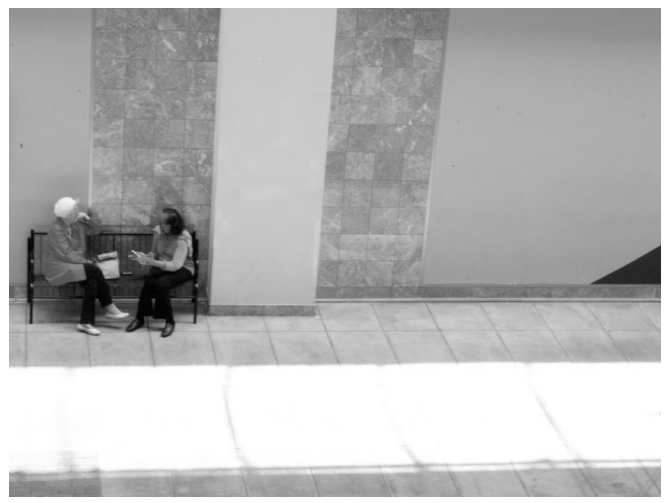

The use of private behavior in Urbana's public spaces is evident by Figure 9, showing two old friends catching up with each other's lives on a public bench in the airy open halls on Lincoln Square Mall on a sunny Tuesday afternoon. The conversation between Subjects $\mathrm{J}$ and $\mathrm{K}$ is clearly a private one though taking place in a public space. Subjects J and K, when interviewed, remarked that they try to meet every once in a while to catch up and chitchat. They found Urbana's public spaces a perfect place to meet and very convenient.

\section{Figure 10}

The food court at Urbana's Lincoln Square Mall: busy lunch hour on a Tuesday and a calm Saturday afternoon
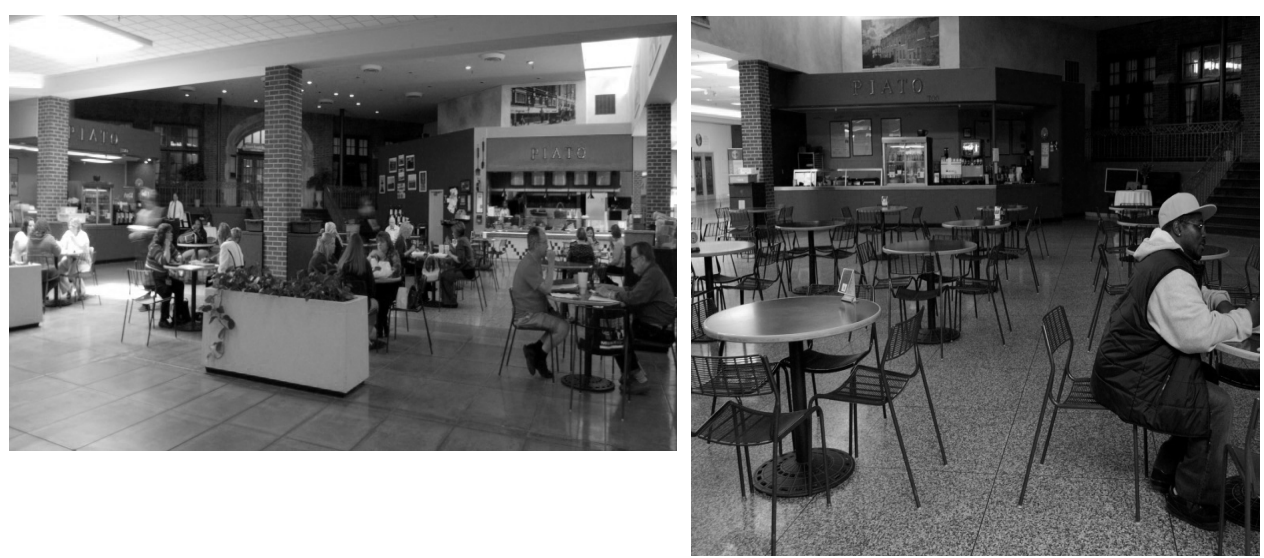
Use of public space for private activities does vary in time. As seen clearly in Figure 10, the Lincoln Square Mall's food court is a main attraction during the workweeks lunch hour where 20 or so people gather to eat lunch, talk, read or continue their work. One subject, subject L, randomly chosen among the crowd was interviewed. Subject L said that she worked at one of the stores in the mall and ate in the food court the majority of the days she works. Compare the top panel to the bottom panel in Figure 10 that shows the weekend relaxation. In the second frame, a single man, Subject M, sits alone working on homework for his alcohol and drug abuse class. Subject L said he needed a quiet place and a place with room to spread out and write so that he could work on his assignment. So he chose the privately-owned public place in Urbana's Lincoln Square Mall. The two frames in Figure 10 show that the amount of use of public space changes over time. Such private behavior in a variety of forms was observed with the high frequency on a daily basis and many places in downtown Urbana.

\section{Conclusions}

By conducting field research through photography in three sites in the college town of Urbana-Champaign, Illinois, we have made some useful observations on social behavior in public space, as presented and discussed earlier. Beyond the analysis in the previous section, some general conclusions are in order, especially with regard to the three research questions raised in the introduction.

First of all, there tends to be a close correlation between the type of social behavior and the kind of public space. Whereas private behavior can be observed equally frequently in all three sites and private-sphere public behavior can also be seen in all three locations, though somewhat less frequently, public-sphere public behavior is primarily observable on the main quadrangle (especially the north end of the Quad) and the adjacent edge area of Campustown. In addition to the few protest and public awareness events reported in the paper, there were multiple other events during the observational period that did not get observed by the research team but were reported in the news media, all taking place in the same Quad-Campustown area. This area is the heart of the University of Illinois where the Illini Union (the student union) is located. The Union carries symbolic power as the Board of Trustees meet on a regularly basis in the Union. It is a key reason for this area, which also has the Alma Matter statue, a symbol of the University just outside of the Union, to draw people who want to make a social and political statement. One may say that this area is the Tiananmen Square, Green Square, or Red Square on a local central Illinois scale.

With the popularity of electronic communications and broadcast discussed by earlier social commentators such as Carpignano et al (1990) and Mitchell (2003) and especially with the recent worldwide phenomenon of the Internet, is the end to public space near? Our research suggests that public space still is an indispensible stage for public-sphere public behavior. Electronic means may be useful for organizing social protests (Mitchell, 2003). The actual protest begins only when the square (like 
Tiananmen Square in 1989) is transformed from a monumental and official space or "a space of representation" into a genuine place of political discourse or "a representational space" (Calhoun, 1989:57). The 2011 social and political protests in North Africa provided additional testimonies to the use of electronic means for organizing social protests to take place in a centrally located, symbolically important public square. In fact, our research shows that even for private recreational behavior such as a fun snowball fight on a snow day, material public space cannot be replaced by virtual public space because the latter serves to organize events to take place in the former.

Finally, our research also reveals public behavior, be it in the public or private sphere, does not always need face-to-face interaction. The type of silent public behavior represented by posters, flyers, pinwheels, and chalk drawings present to people using public places social and political messages. The social interaction through such means is not instantaneous but delayed. However, the effects achieved cannot be ignored because these rather conventional communication devices are convenient and can last a relatively long time (at least several days). They combine some of the advantages of virtual public spaces such as impersonality and ready availability with some of the benefits of real or material public spaces such as viewability and spatial as well as symbolic centrality. They may not be able to replace human physical presence but certainly can initiate political discourse.

\section{References}

1. Arendt, H. (1958). The Human Condition. Chicago: University of Chicago Press.

2. Bankert, E. A. and Robert, J. A. (2006). Institutional Review Board: Management and Function. Sudbury, MA: Jones and Bartlett.

3. Baxter, V. and Kroll-Smith, S. (2005). Normalizing the Workplace Nap: Blurring the Boundaries between Public and Private Space and Time. Current Sociology, 53:33-55.

4. Becker, Howard S. (1974). Photography and Sociology. Studies in the Anthropology of Visual Communication, 1:3-26.

5. Becker, H. S. (1981). Exploring Society Photographically. Chicago, IL: Northwestern University/University of Chicago Press.

6. Becker, H. S. (1995). Visual Sociology, Documentary Photography, and Photojournalism: It's (Almost) All a Matter of Context. Visual Sociology, 10:5-14.

7. Breese, E. B. (2011). Mapping the Variety of Public Spheres. Communication Theory, 21:130-149.

8. Calhoun, C. (1989). Tiananmen, Television and the Public Sphere: Internationalization of Culture and the Beijing Spring of 1989. Public Culture, 2:54-71.

9. Calhoun, C. (1993). Civil Society and Public Sphere. Public Culture, 5:267-280.

10. Calhoun, C. (2010). The Public Sphere in the Field of Power. Social Science History, 34:301-335.

11. Carpignano, P.; Andersen, R.; Aronowitz, S. and Difazio, W. (1990). Chatter in the Age of Electronic Reproduction: Talk Television and the 'Public Mind'. Social Text, 25/26:33-55. 
12. Carr, S.; Francis, M.; Rivlin, L. G. and Stone, A. M. (1992). Public Space. New York: Cambridge University Press.

13. Duneier, M. (2001). Sidewalk. New York: Farrar, Straus and Giroux.

14. Eriksen, E. O. (2005). An Emerging European Public Sphere. European Journal of Social Theory, 8:341-363.

15. Erkip, F. (2003). The Shopping Mall as an Emergent Public Space in Turkey. Environment and Planning, A 35:1073-1093.

16. Gans, H. J. (2002). The Sociology of Space: A User-Centered View. City E Community, 1:329-339.

17. Gieryn, T. F. (2000). A Space for Place in Sociology. Annual Review of Sociology, 26:463-496.

18. Goffman, E. (1963). Behavior in Public Places: Notes on the Social Organization of Gatherings. New York: Free.

19. Goodman, D. (1992). Public Sphere and Private Life: Toward a Synthesis of Current Historiographical Approaches to the Old Regime. History and Theory, 31:1-20.

20. Gumprecht, B. (2007). The campus as a Public Space in the American College Town. Journal of Historical Geography, 33:72-103.

21. Habermas, J. (1989). The Structural Transformation of the Public Sphere. Cambridge, MA: MIT Press.

22. Harper, D. (1988). Visual Sociology: Expanding Sociological Vision. The American Sociologist, 19:54-70.

23. Mitchell, D. (2003). The Right to the City: Social Justice and the Fight for Public Space. New York: Guilford.

24. Oliver, P. E. and Myers, D. J. (1999). How Events Enter the Public Sphere: Conflict, Location, and Sponsorship in Local Newspaper Coverage of Public Events." American Journal of Sociology, 105:38-87.

25. Riley, R. and Manias, E. (2003). "Snap-Shots of Live Theatre: The Use of Photography to Research Governance in Operating Room Nursing. Nursing Inquiry, 10:81-90.

26. Sennett, R. (2010). "Public Realm." Pp. 261-272 in The Blackwell City Reader, edited by Gary Bridge and Sophie Watson. Chichester, UK: Wiley-Blackwell.

27. Tickamyer, A. R. (2000). Space Matters! Spatial Inequality in Future Sociology." Contemporary Sociology, 29:805-813.

28. Tilly, C. (2010). The Rise of the Public Meeting in Great Britain. Social Science History, 34:291-299.

29. Weintraub, J. (1997). The Theory and Politics of the Public/Private Distinction, in: Jeff Weintraub and Krishan Kumar (Eds.). Public and Private in Thought and Practice: Perspectives on a Grand Dichotomy. Chicago: University of Chicago Press:1-42.

30. Weintraub, J. and Kumar, K. (1997). Public and Private in Thought and Practice: Perspectives on a Grand Dichotomy. Chicago: University of Chicago Press.

31. Whyte, W. H. (1980). The Social Life of Small Urban Places. Washington, DC: The Conservation Foundation. 


\section{Tim F. Liao}

University of Illinois, Illinois, USA

e-mail: tfliao@illinois.edu

Adam Rule

University of Illinois, Illinois, USA

Ryanne Ardisana

University of Illinois, Illinois, USA

Alexandra Knicher

University of Illinois, Illinois, USA

A manda Mayo

University of Illinois, Illinois, USA

Corey Sarcu

University of Illinois, Illinois, USA

\section{Društveno ponašanje na javnom prostoru sveučilišnog grada}

\section{Sažetak}

Javni je prostor važno mjesto društvenoga i političkoga djelovanja. U našem istraživanju bavimo se društvenim ponašanjem na javnom prostoru američkoga sveučilišnog grada. Odabrali smo tri lokacije na i oko kampusa Urbana-Champaign Sveučilišta Illinois i promatrali dvije vrste javnoga ponašanja, u domeni javnoga i privatnoga, te privatno ponašanje na odabranim lokacijama. Pokušali smo razumjeti odnos između javnoga mjesta i društvenoga ponašanja, tipove i varijacije društvenoga ponašanja, te važnost materijalnoga, odnosno realnoga javnog prostora. Pokazalo se da se društveno djelovanje u javnoj sferi koncentrira na centralnim, simbolički moćnim javnim mjestima i da, usprkos rastućoj popularnosti virtualnoga javnog prostora, realni ili materijalni prostor i dalje ljudima predstavlja uzbudljiv i živ okoliš za javno i privatno djelovanje.

Ključne riječi: društveno djelovanje, javni prostor, javna sfera, sveučilišni grad, fotografsko promatranje. 